\title{
EFEKTIVITAS PENERAPAN MEDIA PEMBELAJARAN DARING PADA PEMBELAJARAN TEMATIK SEKOLAH DASAR NEGERI 02 BENGKAYANG
}

\author{
Silvester $\mathscr{\oplus}^{1)}$, Pebria Dheni Purnasari $\oplus^{2)}$, dan Margaretha Lidya Sumarni $\oplus^{3)}$ \\ 1,2,3 Pendidikan Guru Sekolah Dasar, Institut Shanti Bhuana \\ 1,2,3 Jl. Bukit Karmel No.1 Bengkayang, 7921, Kalimantan Barat \\ E-mail : silvester@ shantibhuana.ac.id ${ }^{1)}$, pebria.dheni@shantibhuana.ac.id ${ }^{2)}$, margaretha@ shantibhuana.ac.id ${ }^{3)}$
}

\begin{abstract}
ABSTRAK
Tujuan penelitian ini untuk mendeskripsikan efektivitas penerapan media pembelajaran daring serta kendala dan faktor yang dihadapi guru dan peserta didik dalam menerapkan media pembelajaran daring pada pembelajaran tematik di Sekolah Dasar. Metode yang digunakan dalam penelitian ini yaitu metode deskriptif dengan pendekatan kualitatif. Teknik pengumpulan data dalam penelitian ini dengan menggunakan observasi, wawancara dan dokumentasi. Analisis data menggunakan analisis data yang dikembangkan oleh Miles dan Huberman yaitu reduction, data display, dan conclusion drawing. Keabsahan data dalam penelitian ini yaitu dengan menggunakan teknik triangulasi. Berdasarkan hasil penelitian yang dilakukan di SDN 02 Bengkayang ditemukan bahwa pembelajaran tematik dengan menerapkan media pembelajaran daring belum efektif, dikarenakan berbagai kendala dan faktor yang mempengaruhi diterapkannya media pembelajaran daring dalam proses belajar mengajar. Berdasarkan hasil observasi dan wawancara yang dilakukan bersama guru dan peserta didik di SDN 02 Bengkayang ditemukan bahwa dalam proses pembelajaran tematik guru belum menggunakan media pembelajaran daring yang menarik dan sesuai dengan materi pembelajaran, sehingga peserta didik tidak mampu memahami pembelajaran yang diberikan oleh guru secara utuh. Selain itu peserta didik tidak memiliki sarana penunjang seperti smartphone pribadi untuk mengikuti pembelajaran yang menerapkan media pembelajaran daring hal ini membuat peserta didik menggunakan smartphone milik orang tua nya, jaringan internet yang kurang memadai dan kondisi ekonomi keluarga peserta didik berada di tingkat menengah sehingga peserta didik tidak mampu membeli kuota/data internet untuk menunjang proses belajar mengajar yang menerapkan media pembelajaran daring. Guru sebaiknya mengikuti pelatihan mengenai berbagai media pembelajaran berbasis teknologi atau media pembelajaran daring sehingga dapat merancang dan mengelola pembelajaran daring dengan baik dan efektif sesuai dengan perkembangan zaman.
\end{abstract}

Kata Kunci: Media Pembelajaran Daring, Kurikulum 2013, Pembelajaran Tematik, Pendekatan Saintifik, Sekolah Dasar

\section{PENDAHULUAN}

Pendidikan di Indonesia telah mengalami banyak perubahan dengan tujuan mencerdaskan bangsa. Dalam hal ini perubahan diwujudkan dengan adanya perubahan kurikulum, dimana saat ini Kurikulum 2013 yang diterapkan di Indonesia. Sebelum Kurikulum 2013 diterapkan, pemerintah melakukan evaluasi terhadap kurikulum sebelumnya dan melakukan uji coba akan melaksanakan Kurikulum 2013. Kurikulum sebelumnya memiliki beberapa kekurangan, di antaranya beberapa kompetensi yang dibutuhkan misalkan penerapan pendidikan karakter, pembelajaran aktif dalam proses pembelajaran yang secara teori berpusat pada siswa, namun pada kenyataannya masih berpusat pada guru.

Kurikulum 2013 adalah salah satu upaya untuk memperbaiki kurikulum sebelumnya. Diberlakukannya kurikulum 2013 diharapkan dapat menghasilkan lulusan yang berkompeten dan diharapkan dapat meningkatkan hasil belajar siswa dari segi kognitif, afektif, dan psikomotor. Kurikulum 2013 menekankan pada pembentukan karakter siswa. Pembelajaran yang diterapkan dalam kurikulum 2013 adalah pembelajaran tematik terpadu. Kegiatan pembelajaran berbasis tematik didasarkan pada sebuah tema yang di dalam tema tersebut terdiri dari beberapa mata pelajaran yang digabungkan menjadi sebuah tema. (Narati, dkk, 2016) "Thematic learning is defined as a learning that is designed based on a particular theme" bahwa pembelajaran tematik didefinisikan sebagai pembelajaran yang dirancang berdasarkan yang khusus tema. Sejalan dengan yang dinyatakan oleh Abdul Majid (Naziroh \& Muhammadi, 2021) bahwa suatu pembelajaran tematik terpadu memungkinkan siswa baik secara individu ataupun kelompok untuk menggali serta menemukan konsep holistik, autentik, dan bermakna. Pembelajaran tematik Sekolah Dasar di Indonesia, berdasarkan kurikulum tematik terpadu 2013 merupakan integrasi antar disiplin, multidisiplin, dan transdisipliner (Hidayati dkk, 2016). Jadi, pembelajaran tematik di Sekolah Dasar untuk mengintegrasikan dimensi sikap, pengetahuan, dan keterampilan menjadi satu kesatuan, menggabungkan kompetensi dari beberapa pelajaran dasar untuk dihubungkan satu sama lain sehingga saling memperkuat, menggabungkan kompetensi inti dari setiap 
pelajaran sehingga setiap pelajaran masih memiliki kompetensi dasar sendiri dan menghubungkan berbagai mata pelajaran dengan lingkungan di sekitarnya.

Pembelajaran tematik terpadu dalam Kurikulum 2013 didukung adanya penerapan pendekatan saintifik. (Izzuddin, 2021) pendekatan saintifik yaitu aktivitas ilmiah yang meliputi kegiatan mengamati, menanya, mengumpulkan informasi, mengasosiasikan dan mengomunikasikan. Dalam pendekatan saintifik ini yakni membelajarkan siswa untuk dapat mencari informasi dari berbagai sumber dengan tujuan siswa tidak terus bergantung dari informasi guru saja. Dapat dikatakan bahwa pendekatan saintifik merupakan pembelajaran yang berpusat pada siswa (student centred) dengan tujuan mengarahkan siswa untuk aktif dalam mencari dan mengolah informasi. Dalam melaksanakan proses pembelajaran guru sangat diperlukan sebagai fasilitator dan motivator.

Pembelajaran tematik berkaitan dengan cara membelajarkan anak didik secara holistic dan terpadu, konsep atau materi pelajaran termuat dalam suatu tema tertentu sehingga pembelajaran tematik tidak berpedoman pada pengkhususan mata pelajaran (Qondias, Anu, \& Niftalia, 2016). Proses pembelajaran nya menekankan pada pemberian pengalaman langsung dan pembahasan tema guna mengembangkan kompetensi siswa dalam memahami materi pelajaran secara menyeluruh (Wartini, 2016). Pembelajaran tematik menurut Trianto (Muhardini, dkk, 2020) adalah pembelajaran yang dirancang berdasarkan tema-tema tertentu, unit yang tematik adalah epitome dari seluruh bahasa pembelajaran yang memfasilitasi siswa untuk secara produktif menjawab pertanyaan yang dimunculkan sendiri dan memuaskan rasa ingin tahu dengan penghayatan secara alamiah tentang dunia di sekitar mereka. Selain itu pembelajaran tematik adalah salah satu model pembelajaran terpadu yang menggunakan tema untuk mengaitkan beberapa mata pelajaran sehingga dapat memberikan pengalaman bermakna kepada siswa (Depdiknas, 2013).

Keberhasilan akan proses pembelajaran tidak lepas karena dukungan sarana yang menunjang salah satunya adalah dalam penggunaan media pembelajaran (Mahsup, Islahudin, \& Anwar, 2018). Pada praktiknya pembelajaran tematik menuntut siswa untuk aktif dalam pembelajaran sehingga siswa akan mampu menemukan ide-ide terbaik, dengan demikian guru harus bisa menciptakan proses pembelajaran yang menarik. Muklis (Muhardini, 2020) mengemukakan bahwa dengan adanya suatu informasi yang dilakukan dengan teknik yang baru, dengan kemasan yang bagus, serta didukung oleh alat-alat yang berupa sarana atau media akan lebih menarik perhatian siswa untuk belajar. Media pembelajaran yang digunakan bisa secara visual (Kurniawati \& Ahmad, 2018). Secara eksplisit menjelaskan bahwa media pembelajaran meliputi alat yang secara fisik digunakan untuk menyampaikan materi pembelajaran yang terdiri dari buku, tape recorder, kaset, video, kamera, film, slide (gambar bingkai) foto, gambar, grafik, televisi dan computer (Yaumi, 2018).

Oleh karena itu, diperlukan kemampuan profesional guru dalam mengelola dan mengembangkan media pembelajaran yang akan digunakan dalam proses pembelajaran. Terlebih lagi, pada situasi saat ini penyebaran virus Covid-19 yang begitu cepat, membuat semua negara membatasi ruang gerak setiap penduduknya melalui Physical Distancing. Hal tersebut membawa perubahan drastis bagi seluruh lini kehidupan, khususnya dalam dunia pendidikan. Proses belajar mengajar dilaksanakan secara jarak jauh atau Dalam Jaringan (Daring) (J. Crawford dalam Hamid dan Jusmiana, 2020).

Terkhusus di Indonesia, Menteri Pendidikan dan Kebudayaan (MENDIKBUD) menerbitkan Surat Edaran Nomor 4 Tahun 2020 tentang Pelaksanaan Pendidikan Dalam Masa Darurat Coronavirus Disease (Covid-19). Sesuai himbauan resmi tersebut, proses belajar mengajar di seluruh satuan pendidikan dilaksanakan secara Daring atau harus mematuhi protokol kesehatan bagi wilayah berstatus zona hijau. Adapun pembelajaran jarak jauh ini dilaksanakan untuk memberikan pengalaman belajar yang bermakna bagi siswa, tanpa terbebani tuntutan menuntaskan seluruh capaian kurikulum untuk kenaikan kelas maupun kelulusan (Wajdi, 2020).

Sistem pembelajaran daring (dalam jaringan) merupakan sistem pembelajaran tanpa tatap muka secara langsung antara guru dan siswa tetapi dilakukan melalui online yang menggunakan jaringan internet. Guru harus memastikan kegiatan belajar mengajar tetap berjalan, meskipun siswa berada di rumah. Solusinya, guru dituntut dapat mendesain media pembelajaran sebagai inovasi dengan memanfaatkan media daring (online).

Berdasarkan observasi di SDN 02 Bengkayang, didapatkan beberapa guru sudah menerapkan media pembelajaran daring dalam proses pembelajaran. Para guru di SDN 02 Bengkayang menggunakan grup di media sosial seperti Whatsapp (WA), telegram, goggle form, aplikasi zoom ataupun media lainnya sebagai media pembelajaran. Dengan demikian, guru dapat memastikan siswa mengikuti pembelajaran dalam waktu yang bersamaan, meskipun di tempat yang berbeda. Berangkat dari hal tersebut, penelitian ini dilakukan untuk mengetahui keefektifan penerapan media pembelajaran daring pada pembelajaran tematik di SDN 02 Bengkayang.

\section{RUANG LINGKUP}

Ruang lingkup dalam penelitian ini yaitu untuk memaparkan seberapa efektif penerapan media pembelajaran daring pada pembelajaran tematik di SDN 02 Bengkayang serta kendala dan faktor apa saja yang tidak menunjang guru dan peserta didik dalam melaksanakan proses belajar mengajar dengan menerapkan media pembelajaran daring.

\section{BAHAN DAN METODE}


Metode penelitian yang digunakan yaitu metode deskriptif dengan pendekatan kualitatif untuk mendeskripsikan dan menganalisis efektivitas penerapan media pembelajaran daring pada pembelajaran tematik di Sekolah Dasar. Moleong (Yulianto \& Nugraheni, 2021) mengemukakan bahwa penelitian kualitatif adalah penelitian yang mendeskripsikan secara rinci dan mendalam sehingga menghasilkan data yang bersumber dari tulisan atau lisan dari subjek dan objek yang diamati.

Teknik pengumpulan data yang digunakan yaitu observasi, wawancara dan dokumentasi. Analisis data dalam penelitian ini yaitu menggunakan analisis data yang dikembangkan oleh Miles dan Huberman yaitu reduction, data display, dan conclusion drawing. Keabsahan data dalam penelitian ini yaitu dengan menggunakan teknik triangulasi. (Sidiq \& Choiri, 2019) mengungkapkan bahwa triangulasi dalam pengujian kredibilitas ini diartikan sebagai pengecekan data dari berbagai sumber dengan cara, dan berbagai waktu. Fokus dalam penelitian ini yaitu efektivitas media pembelajaran daring pada pembelajaran tematik di SDN 02 Bengkayang.

Media pembelajaran merupakan sarana atau alat yang digunakan untuk menyampaikan informasi berupa materi pembelajaran sehingga terjalin komunikasi antara guru dan siswa dalam proses belajar mengajar untuk mencapai tujuan pembelajaran yang diinginkan. (Sunardi, Sahputra, dan Hidayah, 2021) menyatakan bahwa media pembelajaran adalah segala sesuatu yang dapat menyalurkan informasi dari sumber informasi kepada penerima informasi. Proses belajar mengajar pada dasarnya juga merupakan proses komunikasi, sehingga media yang digunakan dalam pembelajaran disebut media pembelajaran. (Hasanah dkk, 2020) mengemukakan bahwa komunikasi tidak akan berjalan tanpa bantuan sarana penyampai pesan atau media. Pesan yang akan di komunikasikan merupakan isi pembelajaran yang termuat dalam kurikulum yang telah disajikan oleh guru kepada siswa dalam proses pembelajaran. Media pembelajaran daring merupakan media pembelajaran berbasis teknologi berupa platform seperti Whatsapp Group, Zoom, Google Classroom dan lain sebagainya yang dapat di akses melalui komputer, laptop dan smartphone. (Baety \& Munandar, 2021) mengemukakan bahwa daring merupakan akronim dari dalam jaringan yang berarti saling bertukar informasi melalui media yang terhubung dalam jaringan internet. Hal ini senada dengan yang diungkapkan oleh (Dewi, 2020) bahwa pembelajaran daring adalah suatu proses interaksi dalam pembelajaran yang menggunakan komputer dengan akses internet. Pembelajaran daring merupakan implementasi proses belajar mengajar atau pertukaran informasi antara guru dan peserta didik dengan memanfaatkan media pembelajaran daring atau jaringan internet. Dengan memanfaatkan teknologi dalam proses belajar mengajar menjadi salah satu alternatif yang paling tepat diterapkan untuk menunjang berlangsungnya pembelajaran jarak jauh atau pembelajaran daring.

Pembelajaran merupakan interaksi yang dilakukan oleh guru dengan peserta didik dan sumber belajar, agar terjadi proses perolehan ilmu pengetahuan, penguasaan materi dan perubahan sikap yang dialami oleh peserta didik. Sedangkan pembelajaran tematik adalah pembelajaran terpadu atau terintegrasi dari berbagai mata pelajaran yang termuat dalam tema. Rusman (Susila, 2020) mengemukakan bahwa pembelajaran tematik merupakan pembelajaran yang dikemas dalam bentuk tema termuat beberapa mata pelajaran yang dipadukan. Hal ini senada dengan yang diungkapkan oleh (Hafid, dkk, 2019) bahwa pembelajaran tematik adalah pembelajaran yang menggunakan pendekatan dengan melibatkan beberapa muatan mata pelajaran untuk memberikan pengalaman bermakna kepada peserta didik. Menurut (Febriani \& Sudirman, 2021) pembelajaran tematik dapat mendorong peserta didik untuk terlibat aktif dalam proses pembelajaran serta memberikan pengalaman secara langsung kepada peserta didik sehingga minat, motivasi dan bakat dalam diri peserta didik dapat meningkat.

Pembelajaran tematik juga sering disebut dengan pembelajaran terpadu. Menurut Kadir \& Asrohah (Lubis, 2018) mengemukakan bahwa pembelajaran tematik adalah sebuah proses belajar mengajar dengan melibatkan berbagai mata pelajaran kedalam suatu tema untuk memberikan pengalaman bermakna kepada peserta didik melalui pengalaman langsung dan menghubungkannya dengan konsep yang telah dipelajari, dalam pelaksanaan pembelajaran tematik terdapat tiga sasaran utama yaitu paduan materi pembelajaran, paduan prosedur penyampaian dan paduan pengalaman belajar. Penerapan pembelajaran tematik dituntut untuk mampu menyampaikan dan membuat media pembelajaran yang efektif dan efisien untuk diterapkan dalam pembelajaran tematik. Efektivitas pembelajaran tematik ditinjau dari keberhasilan proses belajar mengajar dengan mengintegrasikan materi dari beberapa mata pelajaran menjadi satu tema, menerapkan model dan media pembelajaran yang sesuai serta memberikan pengalaman yang bermakna bagi peserta didik selama mengikuti proses belajar mengajar.

\section{PEMBAHASAN}

Maraknya Covid-19 memberi dampak besar di segala bidang, salah satunya bidang pendidikan. Hal yang paling tampak yaitu perubahan dalam sistem pembelajaran. Sebelumnya sistem pembelajaran yang diterapkan yaitu sistem pembelajaran tatap muka atau luring, kini sistem pembelajaran berubah menjadi sistem pembelajaran daring. Hal ini sejalan dengan yang diungkapkan oleh (Yulianto \& Nugraheni, 2021) Pembelajaran daring dilaksanakan sebagai salah satu cara agar tetap terwujudnya tujuan pendidikan meskipun dalam kondisi pandemi Covid-19, dan upaya untuk mencegah tersebarnya virus covid-19. Pandemi Covid-19 
saat ini menjadikan berubahnya sistem belajar mengajar dimana pada setiap harinya melaksanakan tatap muka berganti menjadi pembelajaran secara daring. Pembelajaran daring tersebut berlaku bagi semua jenjang pendidikan, baik dari Sekolah Dasar sampai perguruan tinggi. (Kurniasari, Dkk, 2020) mengemukakan bahwa pembelajaran diterapkan agar peserta didik tetap bisa belajar tanpa terhalang batasan waktu meskipun pada saat pandemi covid-19.

\subsection{Media Pembelajaran Daring yang digunakan Guru pada Pembelajaran Tematik}

Media pembelajaran sangat penting dalam menunjang proses pembelajaran agar materi pelajaran tersampaikan dengan baik kepada peserta didik. Pertanyaan yang diajukan secara langsung kepada guru di SDN 02 Bengkayang yaitu media pembelajaran apa yang digunakan dalam pembelajaran tematik selama masa pandemi covid-19. Berdasarkan hasil wawancara ditemukan bahwa para guru beberapa guru sudah menggunakan media pembelajaran daring dalam proses belajar mengajar, dengan memanfaatkan berbagai platform yang dapat diakses secara daring atau online. Media pembelajaran daring yang digunakan guru untuk menyampaikan materi dan pemberian tugas yaitu Whatsapp dan goggle form.

Pembelajaran tematik dengan media pembelajaran daring sulit dipahami oleh peserta didik, seharusnya guru dapat memanfaatkan berbagai platform berbasis teknologi informasi sebagai media pembelajaran berupa zoom, goggle meet atau dengan menggunakan video pembelajaran untuk memudahkan guru dalam melakukan interaksi dengan peserta didik dan memberikan penjelasan terkait materi pelajaran. Namun, media pembelajaran ini tidak digunakan oleh para guru sehingga proses belajar mengajar tidak berjalan dengan efektif dan efisien. Hal ini di dukung dari hasil wawancara dengan peserta didik bahwa dalam proses pembelajaran guru tidak menggunakan media pembelajaran yang menarik dalam proses belajar mengajar (Nurhidayati, S., \& Rahayu, A., 2019)

Terdapat kendala dan kekurangan penerapan media pembelajaran daring pada pembelajaran tematik dikarenakan jaringan kurang memadai dan guru tidak dapat berinteraksi secara langsung dengan peserta didik sehingga tidak mengetahui perkembangan yang terjadi pada peserta didik, serta terdapat beberapa peserta didik yang tidak memiliki sarana yang menunjang penerapan media pembelajaran daring.

Berdasarkan hasil wawancara dengan guru dan peserta didik media pembelajaran yang diterapkan selama masa pandemi covid-19 yaitu media pembelajaran daring. Menurut (Hilna, dkk, 2020) pembelajaran daring merupakan sebuah pembelajaran yang dilakukan dalam jarak jauh melalui media berupa internet dan alat penunjang lainnya seperti telepon seluler dan komputer. Media pembelajaran daring yang digunakan oleh guru dalam menunjang proses pembelajaran di SDN 02 Bengkayang yaitu dengan menggunakan platform whatsapp dan goggle form dalam pemberian materi dan tugas.

Kelebihan dalam penggunaan media pembelajaran daring yaitu peserta didik tidak bergantung kepada guru. Guru berperan sebagai fasilitator dalam pembelajaran, sehingga peserta didik dapat mencari jawaban atau sumber belajar lain dengan caranya sendiri, yang dapat diakses melalui internet, Google dan platform yang tersedia. Hal ini didukung oleh temuan (Hilna, dkk, 2020) yang menyatakan bahwa kelebihan dari pembelajaran daring yaitu terdapat kebebasan waktu dan tempat belajar, sehingga dapat membangun motivasi, minat dan antusias belajar peserta didik dengan mencari tahu sendiri cara menyelesaikan masalahnya.

Selain itu, kekurangan dari pembelajaran daring adalah jaringan yang tidak memadai, guru tidak dapat berinteraksi langsung dengan peserta didik sehingga tidak mengetahui perkembangannya yang dicapai serta guru tidak mengetahui apakah pembelajaran yang disampaikan dapat sudah benar-benar dipahami oleh peserta didik atau tidak. Pernyataan tersebut selaras dengan temuan (Hilna, dkk, 2020) yang menyatakan bahwa pembelajaran daring mengakibatkan kurangnya interaksi antara guru dan peserta didik dan keterbatasan dalam jaringan atau kuota internet.

Dalam pelaksanaan pembelajaran tematik melalui media pembelajaran daring menyebabkan peserta didik tidak mudah mengikutinya, dikarenakan materi pelajaran yang disampaikan sulit untuk dipahami, selain itu peserta didik juga tidak memiliki alat penunjang pembelajaran seperti smartphone pribadi peserta didik menggunakan alat atau smartphone orang tuanya. Hal ini selaras dengan temuan (Dewi \& Sadjiarto, 2021) yang menyatakan bahwa pembelajaran yang menerapkan media pembelajaran daring memerlukan media komunikasi seperti smartphone yang dipadukan dengan aplikasi Whatsapp.

\subsection{Kendala yang dihadapi dalam menerapkan Media Pembelajaran Daring pada Pembelajaran Tematik}

Berdasarkan hasil observasi dan wawancara kendala yang dialami dalam penerapan media pembelajaran daring di SDN 02 Bengkayang yaitu sebagian besar peserta didik tidak memiliki smartphone. Hal ini dibuktikan dengan hasil wawancara dengan peserta didik yang mengungkapkan bahwa tidak memiliki smartphone karena keterbatasan ekonomi, sehingga upaya yang dilakukan yaitu dengan menggunakan smartphone milik orang tuanya. Sebagian besar orang tua peserta didik juga menggunakan smartphone untuk bekerja, sehingga upaya yang dilakukan oleh guru dalam memberikan materi pelajaran/tugas yaitu saat orang tua peserta didik sudah tidak bekerja pada malam, sehingga peserta didik dapat tetap mengikuti proses pembelajaran.

Berdasarkan hasil wawancara dengan guru dan peserta didik bahwa penerapan media pembelajaran 
daring pada pembelajaran tematik terkendala oleh jaringan internet yang tidak memadai, sehingga menyebabkan proses pembelajaran tidak berjalan dengan lancar. Hal ini selaras dengan temuan (Kusumaningrum \& Wijayanto, 2020) bahwa penerapan media pembelajaran daring selama masa pandemi covid-19 sering terkendala oleh jaringan internet yang sulit dijangkau, akses internet yang tidak stabil menyebabkan aktivitas pembelajaran daring menjadi tidak lancar sehingga materi tidak tersampaikan dengan baik. Upaya yang dilakukan guru dalam hal tersebut adalah menggunakan Wi-Fi sekolah dan peserta didik menggunakan kartu data internet dengan menyesuaikan jaringan yang ada di lingkungan sekitarnya.

Selain itu, kendala yang dialami yaitu pada kuota/data internet yang dibutuhkan dalam mengakses jaringan internet. Menurut (Juliya \& Herlambang, 2021) kuota merupakan hal utama yang harus dimiliki peserta didik dalam mengakses internet selama pembelajaran daring. Sementara itu, peserta didik di SDN 02 Bengkayang tergolong dalam kondisi ekonomi yang menengah ke bawah tentunya kuota internet menjadi permasalahan karena mereka terkadang tidak memiliki cukup biaya dalam membeli kuota internet.

Upaya yang dilakukan kemdikbud dengan memberikan kemudahan bagi semua orang yang sedang menerapkan media pembelajaran daring dalam menunjang proses pembelajaran yaitu dengan memberikan bantuan kuota internet bagi guru dan peserta didik yang telah mendaftarkan nomor ponsel aktif di sekolah, sehingga bantuan kuota internet dapat menjadi kemudahan bagi peserta didik yang terkendala dalam membeli kuota internet (Juliya \& Herlambang, 2021) .

Pembelajaran tematik dengan media pembelajaran daring sulit untuk laksanakan oleh peserta didik, untuk mengatasi hal tersebut, guru dapat menggunakan media pembelajaran yang sesuai dengan kondisi peserta didik dan guru juga dapat memanfaatkan platform yang tersedia seperti zoom, PPT atau video pembelajaran untuk berinteraksi secara daring atau virtual dengan peserta didik sehingga dapat memaparkan materi pelajaran dengan baik. Hal ini di dukung dengan temuan (Kurnianti \& Nuroso, 2020) yang menyatakan bahwa Penggunaan media zoom dan power point dalam pembelajaran dapat meningkatkan hasil belajar peserta didik pada pembelajaran tematik. Namun, berdasarkan hasil observasi dan wawancara bahwa guru di SDN 02 Bengkayang tidak menggunakan media pembelajaran tersebut. Hal ini diungkapkan oleh peserta didik bahwa guru tidak menggunakan zoom, PPT atau video pembelajaran sebagai media pembelajaran.

Pelaksanaan proses pembelajaran tematik yang dilaksanakan para guru di SDN 02 Bengkayang belum sepenuhnya menerapkan media pembelajaran daring dan para guru juga belum menerapkan media pembelajaran yang menarik dan sesuai dalam pembelajaran, seperti zoom, PPT atau video pembelajaran dikarenakan pendidik memiliki pengetahuan dan kemampuan yang terbatas dalam penggunaan teknologi, jaringan yang tidak memadai, sehingga upaya yang harus dilakukan pendidik adalah mengikuti pelatihan, seminar dan workshop tentang penggunaan media pembelajaran yang menarik dan sesuai dalam pembelajaran daring.

\section{KESIMPULAN}

Berdasarkan hasil penelitian yang dilakukan di SDN 02 Bengkayang ditemukan bahwa pembelajaran tematik dengan menerapkan media pembelajaran daring tidak efektif, dikarenakan berbagai kendala dan ditemukan beberapa faktor yang terjadi dalam proses belajar mengajar. Salah satunya adalah guru belum menggunakan media pembelajaran daring yang menarik dan sesuai dalam penyampaian materi pembelajaran, sehingga peserta didik tidak mampu memahami pembelajaran yang diberikan oleh guru secara utuh. Selain itu peserta didik tidak memiliki sarana penunjang seperti smartphone pribadi dalam mengikuti pembelajaran yang menerapkan media pembelajaran daring, jaringan internet yang kurang memadai dan kondisi ekonomi peserta didik berada di tingkat menengah sehingga peserta didik tidak mampu membeli kuota/ data internet yang dapat menunjang proses belajar mengajar yang menerapkan media pembelajaran daring.

\section{SARAN}

Guru sebagai pendidik disarankan dapat merancang pembelajaran dan media pembelajaran yang menarik, efektif dan efisien sesuai dengan perkembangan zaman dan kondisi lingkungan peserta didik. Guru juga disarankan untuk mengikuti pelatihan mengenai berbagai media pembelajaran yang dapat diterapkan dalam pembelajaran daring yang baik dan efektif untuk diterapkan. Peneliti selanjutnya disarankan untuk mengembangkan penelitian yang relevan dengan variabel yang berfokus pada media pembelajaran daring.

\section{DAFTAR PUSTAKA}

Baety, D. N., \& Munandar, D. R. (2021). Analisis Efektifitas Pembelajaran Daring Dalam Menghadapi Wabah Pandemi Covid19. Edukatif: Jurnal Ilmu Pendidikan, 3(3), 880989.

Dewi, T. A. P., \& Sadjiarto, A. (2021). Pelaksanaan Pembelajaran Daring Pada Masa Pandemi Covid-19. Jurnal Basicedu, 5 (4), 1909-1917.

Dewi, W. A. F. (2020). Dampak Covid-19 terhadap implementasi pembelajaran daring di Sekolah Dasar. Edukatif: Jurnal Ilmu Pendidikan, 2(1), 55-61.

Depdiknas. 2013. Kamus Besar Bahasa Indonesia Pusat Bahasa. Cet. Kelima. Jakarta : PT Gramedia Pustaka Utama.

Febriani, D. A., Hafid, A., \& Sudirman, S. (2021). Analisis Efektivitas Pembelajaran Tematik melalui Daring di Kelas IV SD Inpres 6/86 
Biru. JPPSD: Jurnal Pendidikan dan Pembelajaran Sekolah Dasar, 1(1), 45-58.

Hasanah, A., Lestari, A. S., Rahman, A. Y., \& Daniel, Y. I. (2020). Analisis aktivitas belajar daring mahasiswa pada pandemi Covid-19.

Hafid, A. (2019). Efektifitas Penerapan Pendidikan Karakter Pada Kurikulum 2013 Pembelajaran Tematik Di Sekolah Dasar Inpres 6/75 Ta'Tanete Riettang Kabupaten Bone. JIKAP PGSD: Jurnal Ilmiah Ilmu Kependidikan, 3(3), 283-293.

Hilna, P., Maula, H. L., \& Uswatun, A. D. (2020). Analisis Proses Pembelajaran dalam Jaringan (DARING) Masa Pandemi COVID-19 pada Pendidik Sekolah Dasar. Jurnal Basicedu, 4 (4), 861-872.

Hidayati, W. (2016). Implementation Of Curriculum 201 In Primary School Sleman Yogyakarta. Journal of Research \& Method in Education (IOSRJRME), 7-12.

Hamid, N., \& Jusmiana, A. (2020). Efektivitas Pembelajaran Daring Menggunakan Model Kooperatif Tipe Team Assisted Individualization (TAI). Pedagogy: Jurnal Pendidikan Matematika, 5(2), 66-80.

Izzuddin, A. (2021). Implementasi Pendekatan Saintifik pada Pembelajaran Daring Selama Masa Pandemi Covid-19 di Lembaga Pendidikan Dasar. AS-SABIQUN, 3(1), 45-63.

Juliya, M., \& Herlambang, Y. T. (2021). Analisis Problematika Pembelajaran Daring dan Pengaruhnya terhadap Motivasi Belajar Siswa. Jurnal Genta Mulia, 12 (1), 281-294.

Kurniawati, W., \& Ahmad, M. (2018). Analisis Pembuatan Media Pembelajaran dalam Mata Kuliah Pendidikan Multimedia oleh Mahasiswa Program Studi Teknologi Pendidikan IKIP Mataram. Jurnal Kependidikan: Jurnal Hasil Penelitian dan Kajian Kepustakaan di Bidang Pendidikan, Pengajaran dan Pembelajaran, 4(2), 215-219.

Kurnianti, I. D., \& Nuroso, H. (2020). Peningkatan Hasil Belajar Peserta Didik pada Pembelajaran Tematik Kelas 1 Tema 4 Sub Tema 2 melalui Pembelajaran Zoom dengan Media Power Point SD Negeri 01 Lambur Kecamatan Kandangserang Kabupaten Pekalongan. Jurnal Pendidikan Dan Profesi Pendidik, 6 (1), 114125.

Kusumaningrum, B., \& Wijayanto, Z. (2020). Apakah Pembelajaran Matematika secara Daring Efektif. Jurnal Matematika Kreatif-Inovatif, 11 (2), 136-142.

Kurniasari, A., Pribowo, F. S. P., \& Putra, D. A. (2020). Analisis efektivitas pelaksanaan belajar dari rumah (BDR) selama pandemi Covid-19. Jurnal Review Pendidikan Dasar: Jurnal Kajian
Pendidikan Dan Hasil Penelitian, 6(3), 246253.

Lubis, M. A. (2019). Pembelajaran tematik di SD/MI: Pengembangan kurikulum 2013. Yogyakarta: Penerbit Samudra Biru (Anggota IKAPI)

Mahsup, M., Islahudin, I., \& Anwar, Y. S. (2018). Pelatihan Penggunaan Media Pembelajaran Untuk Meningkatkan Pemahaman Dalam Menentukan Volume Bangun Ruang Bagi Siswa Sekolah Dasar. Selaparang Jurnal Pengabdian Masyarakat Berkemajuan,2(1), 27-30.

Muhardini, S., Rahman, N., Mahsup, M., Sudarwo, R., Anam, K., \& Fujiaturrahman, S. (2020). Pengembangan media pembelajaran box nusantara untuk membentuk kemampuan memahami konsep tematik pada siswa sekolah dasar. Jurnal Kependidikan: Jurnal Hasil Penelitian dan Kajian Kepustakaan di Bidang Pendidikan, Pengajaran dan Pembelajaran, 6(2), 284-291.

Naziroh, N., \& Muhammadi, M. (2021). Peningkatan Hasil Belajar Siswa Menggunakan Model Kooperatif Group Investigation (GI) dalam Pembelajaran Tematik Terpadu di Kelas V/A Sekolah Dasar. Journal of Basic Education Studies, 4(1), 3462-3472.

Nurhidayati, S., \& Rahayu, A. (2019, April). Pendekatan Saintifik Dalam Pembelajaran Tematik di Sekolah Dasar. In Prosiding Seminar Nasional PGSD UST (Vol. 1).

Narati, Y., \& Dkk. (2016). Tematic Learning Implemantation in Elementary School.(Phenomenology Student in Pamotan SDN 01 Majangtengah Malang. International Journal of Science and Research, Vol. 5, No. 11.

Qondias, D., Anu, L. E., \& Niftalia, I. (2016). Pengembangan Media Pembelajaran Tematik Berbasis Mind Maping Sd Kelas Iii Kabupaten Ngada Flores. Jurnal Pendidikan Indonesia (JPI), Vol. 5, No. 2.

Sidiq, U., \& Choiri, M. (2019). Metode Penelitian Kualitatif Di Bidang Pendidikan. Ponorogo: CV. Nata Karya.

Sunardi, D., Sahputra, E., \& Hidayah, A. K. (2021). Pelatihan Pembuatan Media Pembelajaran Berbasis Multimedia Untuk Meningkatkan Kualitas Pembelajaran Bagi Guru Sma Muhammadiyah 4 Kota Bengkulu. JPMTT (Jurnal Pengabdian Masyarakat Teknologi Terbarukan), 1(1), 29-34.

Susila, D. (2020). Peningkatan Hasil Belajar Siswa Tematik Terpadu Menggunakan Model PBL di Kelas IV SDN 15 Pasaman. Jurnal Pendidikan Tambusai, 4(3), 2826-2832.

Wajdi, M. B. N., Kuswandi, I., Al Faruq, U., Zulhijra, Z., Khairudin, K., \& Khoiriyah, K. (2020). 
Education Policy Overcome Coronavirus, A Study of Indonesians. EDUTEC: Journal of Education And Technology, 3(2), 96-106.

Wartini, A. N. A. (2016). Kebijakan Pembelajaran Tematik Integratif Dalam Kurikulum 2013 Paud. Al-Afkar: Jurnal Keislaman \& Peradaban, 3(1).

Yaumi, M. (2018). Media dan Teknologi Pembelajaran. Jakarta: Prenadamedia Group (Divisi Kencana).

Yulianto, D., \& Nugraheni, A. S. (2021). Efektivitas Pembelajaran Daring Dalam Pembelajaran
Bahasa Indonesia. Decode: Jurnal Pendidikan Teknologi Informasi, 1(1), 33-42.

\section{UCAPAN TERIMA KASIH}

Ucapan terima kasih disampaikan kepada PRPM Institut Shanti Bhuana atas dukungan nya baik secara materi maupun motivasi. Ucapan terima kasih juga disampaikan kepada para guru dan peserta didik SDN 02 Bengkayang atas kerja sama baiknya hingga penelitian ini selesai. 